\title{
THREATENED LYCOPHYTES AND FERNS IN FOUR PROTECTED AREAS OF MINDANAO, PHILIPPINES
}

\author{
Fulgent P. Coritico*, Victor B. Amoroso \\ Central Mindanao University, Philippines \\ *e-mail:cfulgent@gmail.com
}

Received: 15.04.2020. Revised: 31.07.2020. Accepted: 04.10.2020.

\begin{abstract}
There are nearly a thousand threatened species of vascular plants in the Philippines and of which about $12 \%$ are lycophytes and ferns. However, there are not enough data on the distribution of the species. Thus, the threatened lycophytes and ferns were determined based on field surveys in four protected areas in Mindanao, namely Mt. Apo Natural Park, Mt. Kitanglad Range Natural Park, Mt. Malindang Range Natural Park, and Mt. Hamiguitan Range Wildlife Sanctuary. The conservation status assessment was based on the Department of Environment and Natural Resources DAO 2017-11 updated list of threatened plants of the Philippines. A total of 45 species of threatened lycophytes and ferns was documented belonging to 16 families and 25 genera. Of these, three species are Critically Endangered, 23 Endangered, 15 Vulnerable, and three are other threatened species. Families with the highest number of threatened species are Cyatheaceae, Polypodiaceae, Lycopodiaceae, Ophioglossaceae, and Psilotaceae. The Critically Endangered species are Platycerium coronarium, Phlegmariurus magnusianus, and Helminthostachys zeylanica. The threatened species endemic to the Philippines are Phlegmariurus magnusianus, Alsophila apoensis, A. atropurpurea, A. hermannii, A. fuliginosa, A. heterochlamydea, A. negrosiana, A. rufopannosa, Lindsaea hamiguitanensis, Tmesipteris zamorarum, Aglaomorpha cornucopia, and A. sagitta. The highest number of threatened taxa was observed in the Mt. Apo Natural Park (29 species), followed by the Mt. Kitanglad Range Natural Park (28 species), Mt. Malindang Range Natural Park (27 species), with the lowest number in the Mt. Hamiguitan Range Wildlife Sanctuary (19 species). Most of the species were recorded in the lower and upper montane forests. The occurrence of threatened and endemic lycophytes and ferns in the four protected areas calls for a strict implementation of the ordinances necessary for a long term conservation and protection of the species.
\end{abstract}

Key words: endangered species, endemism, conservation, mountain ecosystems, pteridophytes

\section{Introduction}

Pteridophytes include the so-called ferns and fern allies, the latter so-called because of their shared life cycle as spore-dispersing vascular plants (Amoroso et al., 2016a,b). However, recent analyses of morphological and molecular data revealed that pteridophytes are paraphyletic, and the boundary within them has been withdrawn to distinguish lycophytes and ferns (monilophytes) (Smith et al., 2006; PPG I, 2016). There are 11916 estimated species of ferns and lycophytes throughout the world (PPG I, 2016). About 4500 species occur in Southeast Asia, which is more than one third of the world diversity (Moran, 2008; Ebihara et al., 2012). In the Philippines, there are 1100 species of lycophytes and ferns distributed among 154 genera and 34 families (Barcelona, 2011-2020; Amoroso et al., 2016b) and ca. 632 species $(57 \%)$ are found on Mindanao Island (Amoroso et al., 2009).

Mindanao Island is the second largest island in the Philippine archipelago and has an enormous numbers of endangered, endemic and economically important species of flora and fauna. This island has a total of 41 Protected Areas (PAs) classified as national parks, natural parks, natural monuments, protected landscapes and seascapes, resource reserves, wildlife sanctuaries, marine reserves, watershed forest reserves, natural biotic areas, and wilderness areas based on the National Integrated Protected Areas System (NIPAS) Act of 1992.

Mt. Apo Natural Park (MANP), Mt. Kitanglad Range Natural Park (MKRNP), Mt. Malindang Range Natural Park (MMRNP) and Mt. Hamiguitan Range Wildlife Sanctuary (MHRWS) are some of the Protected Areas in Mindanao Island. These mountain ecosystems are also considered as ASEAN Heritage Parks. Moreover, MHRWS was listed as a UNESCO World Heritage site in 2014. All of these four Protected Areas are also Philippine Long-Term Ecological Research (LTER) sites (Kim et al., 2017) and home to different endemic species of plants and animals (Amoroso et al., 2009; Mohagan et al., 2015, 2018; Amoroso et al., 2015, 2018). Initial listing of the plants in the area was provided by Amoroso et al. (2006) in Mt. Malindang, Amoroso et al. (2009) in Mt. Hamiguitan, and Amoroso et al. (2011) in Mt. Kitanglad. A list of the threatened plant species on Mindanao Island was provided by Lumista et al. (2016) and Aribal \& Buot (2009). Also, Fernando et al. (2008) listed 202 species of ferns and lycophytes 
as nationally threatened in the Philippines. However, their list did not provide complete information about the distributions of the species on Mindanao and they followed the old assessment of the Department of Environment and Natural Resources (DENR).

Thus, this paper provides a comprehensive and updated list of threatened lycophytes and ferns, species conservation assessment, their distribution through field validation in the four selected Protected Areas on Mindanao, Philippines. This paper serves as basis for strict protection and conservation of the remaining threatened endemic species of lycophytes and ferns in the four Protected Areas on Mindanao Island.

\section{Material and Methods \\ Species inventory}

Prior to the conduct of the field work, a gratuitous permit from the four Protected Areas on Mindanao was obtained from the DENR regional offices. An inventory of lycophytes and ferns was then conducted by the authors from January 2014 to December 2015 through repeated transect walks from the foot of the mountain to the highest point in Mt. Apo Natural Park, North Cotabato $\left(125.275000^{\circ} \mathrm{N}\right.$, $7.260833^{\circ}$ E), Mt. Kitanglad Range Natural Park,
Bukidnon $\left(124.916700^{\circ} \mathrm{N}, 5.083333^{\circ} \mathrm{E}\right)$, Mt. Malindang Range Natural Park, Misamis Occidental $\left(123.600000^{\circ} \mathrm{N}, 8.283333^{\circ} \mathrm{E}\right)$, and Mt. Hamiguitan Range Wildlife Sanctuary, Davao Oriental $\left(126.166700^{\circ} \mathrm{N}, 6.716666^{\circ} \mathrm{E}\right)$ (Fig. 1). Another field inventory was conducted by researchers from Central Mindanao University and the Botanical Research Institute of Texas from 2016 to 2019. These sites were selected because they are considered as Long Term Ecological Research (LTER) sites on Mindanao and also designated as ASEAN Heritage Parks.

\section{Collection, processing, and identification of specimens}

A minimum of two fertile fronds of each species was collected and processed using the wet method (Hodge, 1947). All herbarium specimens were deposited at the Central Mindanao University Herbarium (CMUH) and the California Academy of Sciences (CAS). All the specimens were identified by the authors using monographs, e-floras and other publications like Copeland (1958), the Flora Malesiana Series and digitised plant specimens available in Global Plants on JSTOR (https://plants.jstor.org/). The classifications were based on PPG I (2016).

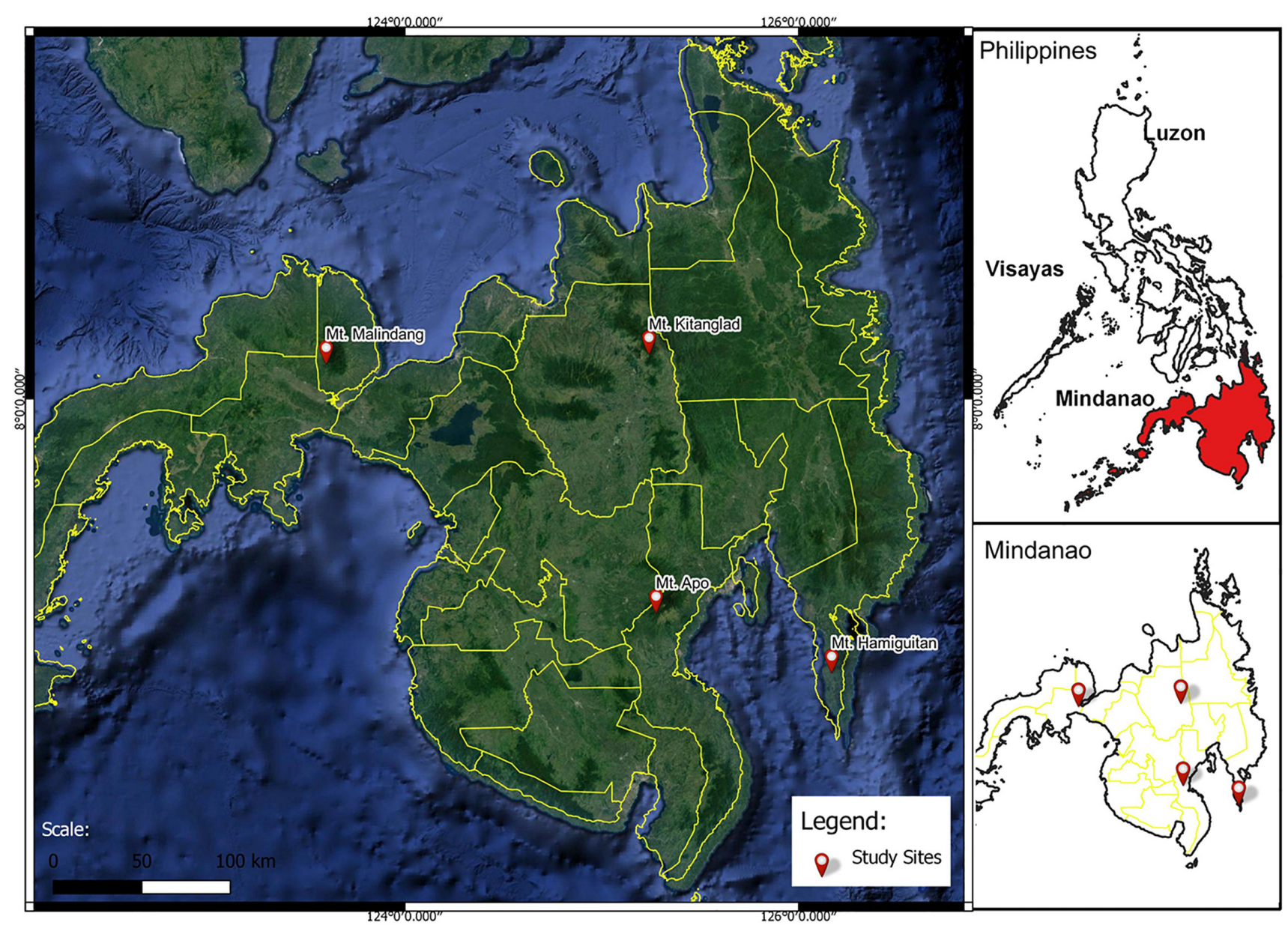

Fig. 1. Location map showing the four selected Protected Areas on Mindanao, Southern Philippines. 
Assessment of the conservation status and distribution

The assessment of the conservation status of the species was based on the updated national list of threatened plants in the Philippines, following the criteria for determination of threatened plant species and their categories of the Department of Environment and Natural Resources (DENRDAO, 2017). The categories are as follows: Critically Endangered (CR), Endangered (EN), Vulnerable (VU) and Other Threatened Species (OTS), which is equivalent to Near Threatened of the International Union for Conservation of Nature (IUCN). This is the latest assessment on the national list of threatened plants in the Philippines made by the Philippine Plant Conservation Committee (PPCC) organised by DENR. The assessments of the conservation status of the species in the country are updated every five years. Information from this list serves as the basis for national environmental policy for the Protected Area Management Board (PAMB) of the Protected Areas and Local Government Units (LGUs) for strictly monitoring and protecting the endangered plant species. The general data on the distribution of species outside the four Protected Areas was based on Barcelona (20112020) and Lindsay \& Middleton (2012-2020), with data for some species complemented by field observations of the authors.

\section{Species richness}

A total of 45 species, six species of lycophytes and 39 of ferns, in the four Protected Areas are threatened, comprising 16 families and 25 genera. The families with the highest number of threatened taxa are Cyatheaceae (ten species), Polypodiaceae (nine species), Lycopodiaceae (five species), and Ophioglossaceae and Psilotaceae with three species each. In these families, some species have high economic importance as ornamental and medicinal plants (Amoroso, 2013; Magtoto $\&$ Austria, 2017). Of the 45 species recorded in the four Protected Areas on Mindanao, three species are considered as Critically Endangered taxa, 23 Endangered, 15 Vulnerable and three Other Threatened Species (Table).

Notes and distribution are provided below for the six prioritised species since three species are Critically Endangered taxa, namely Platycerium coronarium (Konig) Desv., Phlegmariurus magnusianus (Herter) A.R.Field \& Testo, and Helminthostachys zeylanica (L.) Hook., and the other three species are threatened and Mindanao Island endemics, Alsophila hermannii R.M.Tryon, A. rufopannosa (Christ) R.M.Tryon and Lindsaea hamiguitanensis Karger \& V.B.Amoroso.

\section{Critically Endangered species}

Platycerium coronarium (König ex Müller) Desv.

Platycerium coronarium is a common, ornamental plant characterised by strongly dimorphic fronds with dichotomous nest leaves and pendulous dichotomously branched fertile fronds (Fig. 2A). It is commonly sold in flower gardens in big cities like Cagayan de Oro City and Davao City on Mindanao and Manila City on Luzon for a very expensive price. This species is considered as Critically Endangered because of its limited distribution in the wild and over-collection as an ornamental plant. In this study, it was observed only within the Mt. Hamiguitan Range Wildlife Sanctuary, Davao Oriental as an epiphyte on Shorea polysperma Merr. and Tristaniopsis decorticata (Merr.) Peter G.Wilson \& J.T.Waterh. However, a new population of $P$. coronarium has recently been discovered by the authors in the Mt. Pantaron Range, Bukidnon in Central Mindanao, which is not a Protected Area.

Distribution. Borneo, Cambodia, Laos, Myanmar, Peninsular Malaysia, Singapore, Sumatra, Thailand, Vietnam. Philippines: Luzon and Mindanao (Mt. Hamiguitan Range Wildlife Sanctuary and Mt. Pantaron Range).

\section{Phlegmariurus magnusianus (Herter)}

\section{A.R.Field \& Testo}

Phlegmariurus magnusianus (Lycopodiaceae) is an epiphytic fern with pendulous stems, which are twice to three times isodichotomously branched, and with narrow-lanceolate, acuminate crowded leaves arranged in close spirally whorled (Fig. 2B). Species in this family are locally known as «salindugok or ikog sa iring», and commonly harvested by the local people in different parts of the country and sold very cheaply. This species was found in Mt. Apo Natural Park and Mt. Malindang Range Natural Park where it grows epiphytically on trees at about 3-10 m high. Only a few individuals of this species were observed.

Distribution. This species is endemic to the Philippines, known from Luzon and Mindanao (Mt. Apo Natural Park and Mt. Malindang Range Natural Park). 
Table. List and distribution of threatened lycophytes and ferns in the four Protected Areas of Mindanao, Philippines

\begin{tabular}{|c|c|c|c|c|c|c|c|c|c|}
\hline \multirow[b]{2}{*}{ Family } & \multirow[b]{2}{*}{ Species } & \multirow{2}{*}{$\begin{array}{c}\text { National Red } \\
\text { List status }\end{array}$} & \multirow{2}{*}{$\begin{array}{c}\text { Accession } \\
\text { number } \\
(\mathrm{CMUH})\end{array}$} & \multicolumn{4}{|c|}{ Protected Areas } & \multirow[b]{2}{*}{ Forest types } & \multirow[b]{2}{*}{$\begin{array}{l}\text { Altitude } \\
\text { (m a.s.1.) }\end{array}$} \\
\hline & & & & $\begin{array}{l}\text { Mt. } \\
\text { Apo }\end{array}$ & \begin{tabular}{|c|} 
Mt. \\
Kitanglad
\end{tabular} & \begin{tabular}{|c|} 
Mt. \\
Malindang
\end{tabular} & \begin{tabular}{|c|} 
Mt. \\
Hamiguitan \\
\end{tabular} & & \\
\hline Aspleniaceae & Asplenium vittaeforme Cav. & $\begin{array}{l}\text { VU A1cd; } \\
\text { B2c }\end{array}$ & $\begin{array}{l}00011501 ; \\
00006507 ; \\
00011481 ; \\
00011490\end{array}$ & + & + & + & + & $\mathrm{LM} / \mathrm{UM} / \mathrm{MF}$ & $\begin{array}{l}1000-1500 \\
1500-2300 \\
2300-2600\end{array}$ \\
\hline Athyriaceae & Diplazium costulisorum (Copel.) C.Chr. & EN A1 & $\begin{array}{l}00011508 \\
00011519\end{array}$ & + & + & - & - & $\mathrm{UM} / \mathrm{MF}$ & $\begin{array}{l}1500-2300 \\
2300-2600\end{array}$ \\
\hline Blechnaceae & Diploblechnum fraseri (A.Cunn.) De Vol & VU A1c & $\begin{array}{l}00007403 \\
00011479\end{array}$ & - & + & + & - & LM/UM & \begin{tabular}{|}
$1000-1500$ \\
$1500-2300$
\end{tabular} \\
\hline Blechnaceae & $\begin{array}{l}\text { Oceaniopteris egregia (Copel.) Gasper } \\
\& \text { Salino }\end{array}$ & VU A1c & $\begin{array}{l}00011503 ; \\
00005890 \\
00011480 ; \\
00011480\end{array}$ & + & + & + & + & LM/UM & $\begin{array}{r}1000-1500 \\
1500-2300\end{array}$ \\
\hline Cyatheaceae & *Alsophila apoensis (Copel.) R.M.Tryon & EN A1cd & 00008377 & + & - & - & - & LM/UM & $\begin{array}{c}1000-1500 \\
1500-2300\end{array}$ \\
\hline Cyatheaceae & *Alsophila atropurpurea (Copel.) C.Chr. & EN A1cd & $\begin{array}{l}00008382 ; \\
00004947 ; \\
00009634\end{array}$ & + & + & + & - & $\mathrm{LM} / \mathrm{UM}$ & $\begin{array}{r}1000-1500 \\
1500-2300\end{array}$ \\
\hline Cyatheaceae & *Alsophila fuliginosa Christ & VU A1cd & $\begin{array}{l}00011502 ; \\
00004946\end{array}$ & + & + & - & - & LM/UM & $\begin{array}{r}1000-1500 \\
1500-2300 \\
\end{array}$ \\
\hline Cyatheaceae & *Alsophila hermannii R.M.Tryon & EN A1cd & $\begin{array}{l}00008375 \\
00011525\end{array}$ & + & + & - & - & LM/UM & $\begin{array}{r}1000-1500 \\
1500-2300 \\
\end{array}$ \\
\hline Cyatheaceae & $\begin{array}{l}\text { *Alsophila heterochlamydea (Copel.) } \\
\text { R.M.Tryon }\end{array}$ & VU A1cd & 00009780 & + & - & - & - & LM/UM & $\begin{array}{r}1000-1500 \\
1500-2300 \\
\end{array}$ \\
\hline Cyatheaceae & *Alsophila negrosiana (Christ) R.M.Tryon & VU A1cd & 00009629 & - & - & + & - & LM/UM & $\begin{array}{r}1000-1500 \\
1500-2300 \\
\end{array}$ \\
\hline Cyatheaceae & *Alsophila rufopannosa (Christ) R.M.Tryon & EN B1 & 00009630 & - & - & + & - & LM/UM & $\begin{array}{r}1000-1500 \\
1500-2300\end{array}$ \\
\hline Cyatheaceae & Sphaeropteris elmeri (Copel.) R.M.Tryon & VU A1cd & $\begin{array}{l}00009775 \\
00011514 ; \\
00009628 \\
00011491 \\
\end{array}$ & + & + & + & + & $\mathrm{LF} / \mathrm{LM}$ & $\begin{array}{c}<1000 \\
1000-1500\end{array}$ \\
\hline Cyatheaceae & Sphaeropteris glauca (Blume) R.M.Tryon & EN A1cd & $\begin{array}{l}00011509 ; \\
00011528 ; \\
00009627 \\
00009640\end{array}$ & + & + & + & + & $\mathrm{LF} / \mathrm{LM} / \mathrm{UM}$ & $\begin{array}{c}<1000 \\
1000-1500 \\
1500-2300\end{array}$ \\
\hline Cyatheaceae & $\begin{array}{l}\text { Sphaeropteris lepifera (J.Sm. ex Hook.) } \\
\text { R.M.Tryon }\end{array}$ & EN A1cd & $\begin{array}{l}00008374 \\
00011561 \\
00008409\end{array}$ & + & + & + & - & LM/UM & $\begin{array}{r}1000-1500 \\
1500-2300\end{array}$ \\
\hline Davalliaceae & Davallia solida (G.Forst.) Sw. & OTS & $\begin{array}{l}00011504 ; \\
00006744 ; \\
00011565 ; \\
00011492\end{array}$ & + & + & + & + & LM/UM & $\begin{array}{r}1000-1500 \\
1500-2300\end{array}$ \\
\hline Dicksoniaceae & Dicksonia mollis Holttum & EN A1cd & $\begin{array}{l}00011511 ; \\
00006436 ; \\
00009638\end{array}$ & + & + & + & - & LM/UM & $\begin{array}{r}1000-1500 \\
1500-2300\end{array}$ \\
\hline Lindsaeaceae & $\begin{array}{l}\text { *Lindsaea hamiguitanensis Karger \& } \\
\text { V.B.Amoroso }\end{array}$ & VU A1c & 00011505 & - & - & - & + & LM & $1000-1500$ \\
\hline Lycopodiaceae & Phlegmariurus carinatus (Desv.) Ching & EN A1cd & $\begin{array}{l}00011523 ; \\
00011563\end{array}$ & + & + & - & - & LM/UM & $\begin{array}{r}1000-1500 \\
1500-2300 \\
\end{array}$ \\
\hline Lycopodiaceae & $\begin{array}{l}\text { * Phlegmariurus magnusianus (Herter) } \\
\text { A.R.Field \& Testo }\end{array}$ & CR A1 & $\begin{array}{l}00011513 ; \\
00011482\end{array}$ & + & - & + & - & LM/UM & $\begin{array}{r}1000-1500 \\
1500-2300 \\
\end{array}$ \\
\hline Lycopodiaceae & Phlegmariurus phlegmaria (L.) Holub & EN A2 & $\begin{array}{l}00011515 ; \\
00004628 ; \\
00011485\end{array}$ & + & + & + & - & LM/UM & $\begin{array}{c}1000-1500 \\
1500-2300\end{array}$ \\
\hline Lycopodiaceae & $\begin{array}{l}\text { Phlegmariurus salvinioides (Herter) } \\
\text { Ching }\end{array}$ & EN A1cd & $\begin{array}{l}00011518 \\
00011483\end{array}$ & + & - & + & - & LM & $1000-1500$ \\
\hline Lycopodiaceae & $\begin{array}{l}\text { Phlegmariurus squarrosus (G.Forst.) } \\
\text { Á.Löve \& D.Löve }\end{array}$ & EN A1cd & $\begin{array}{l}00011512 \\
00007315 \\
00011484 ; \\
00011474\end{array}$ & + & + & + & + & LM & $1000-1500$ \\
\hline Marattiaceae & Angiopteris evecta (G.Forst.) Hoffm. & OTS & $\mid \begin{array}{c}00011529 ; \\
00011567 ; \\
00011534\end{array}$ & + & + & + & - & $\mathrm{LM} / \mathrm{UM}$ & $\begin{array}{r}1000-1500 \\
1500-2300\end{array}$ \\
\hline
\end{tabular}




\begin{tabular}{|c|c|c|c|c|c|c|c|c|c|}
\hline \multirow[b]{2}{*}{ Family } & \multirow[b]{2}{*}{ Species } & \multirow[b]{2}{*}{$\begin{array}{c}\text { National Red } \\
\text { List status }\end{array}$} & \multirow{2}{*}{$\begin{array}{c}\text { Accession } \\
\text { number } \\
(\mathrm{CMUH})\end{array}$} & \multicolumn{4}{|c|}{ Protected Areas } & \multirow[b]{2}{*}{ Forest types } & \multirow{2}{*}{$\begin{array}{l}\text { Altitude } \\
\text { (m a.s.l.) }\end{array}$} \\
\hline & & & & $\begin{array}{l}\text { Mt. } \\
\text { Apo }\end{array}$ & $\begin{array}{c}\text { Mt. } \\
\text { Kitanglad }\end{array}$ & \begin{tabular}{|c|} 
Mt. \\
Malindang
\end{tabular} & \begin{tabular}{|c|} 
Mt. \\
Hamiguitan
\end{tabular} & & \\
\hline Marattiaceae & Christensenia aesculifolia (Blume) Maxon & EN B1 & $\begin{array}{l}00011564 ; \\
00011475\end{array}$ & - & + & + & - & LM & $1000-1500$ \\
\hline Ophiglossaceae & $\begin{array}{l}\text { Botrychium daucifolium Wall. ex Hook. } \\
\text { \& Grev. }\end{array}$ & VU A1 & $\begin{array}{l}00011522 ; \\
00008291 ; \\
00011477\end{array}$ & + & + & + & - & LM & $1000-1500$ \\
\hline Ophiglossaceae & Helminthostachys zeylanica (L.) Hook. & $\mathrm{CR}$ & 00011478 & - & - & + & - & $\mathrm{LF}$ & $<1000$ \\
\hline Ophiglossaceae & Ophioderma pendula C.Presl & EN A1cd & $\begin{array}{l}00011558 \\
00007731 \\
00011476 ; \\
00011506\end{array}$ & + & + & + & + & LM/UM & $\begin{array}{l}1000-1500 \\
1500-2300\end{array}$ \\
\hline Osmundaceae & Plenasium banksiifolium (C.Presl) C.Presl & OTS & $\begin{array}{l}00011542 \\
00006456 \\
00011548 \\
00011493\end{array}$ & + & + & + & + & $\mathrm{LM} / \mathrm{UM}$ & $\begin{array}{l}1000-1500 \\
1500-2300\end{array}$ \\
\hline Polypodiaceae & $\begin{array}{l}\text { *Aglaomorpha cornucopia (Copel.) } \\
\text { M.C.Roos }\end{array}$ & VU A1a & $\begin{array}{l}00011539 ; \\
00007179 ; \\
00011550\end{array}$ & + & + & + & - & LM/UM & $\begin{array}{l}1000-1500 \\
1500-2300\end{array}$ \\
\hline Polypodiaceae & Aglaomorpha heraclea (Kunze) Copel. & VU A1a & $\begin{array}{l}00011547 \\
00007845 \\
00011543 \\
\end{array}$ & + & + & + & - & LM/UM & $\begin{array}{l}1000-1500 \\
1500-2300\end{array}$ \\
\hline Polypodiaceae & $\begin{array}{l}\text { *Aglaomorpha sagitta (Christ) } \\
\text { Hovenkamp \& S. Linds. }\end{array}$ & VUA1c & $\begin{array}{l}00011544 \\
00011551 \\
00011538\end{array}$ & + & + & + & - & LM/UM & $\begin{array}{l}1000-1500 \\
1500-2300\end{array}$ \\
\hline Polypodiaceae & Aglaomorpha splendens (J.Sm.) Copel. & VUA1c & $\begin{array}{l}00011524 \\
00006677\end{array}$ & + & + & - & - & $\mathrm{LM} / \mathrm{UM}$ & $\begin{array}{l}1000-1500 \\
1500-2300\end{array}$ \\
\hline Polypodiaceae & Aglaomorpha speciosa (Blume) M.C.Roos & VUA1c & 00011521 & - & - & - & + & LM & $<1000$ \\
\hline Polypodiaceae & Lecanopteris deparioides (Ces.) Baker & EN A1c; B2c & $\begin{array}{l}00011533 \\
00011494\end{array}$ & - & - & + & + & LM/UM & $\begin{array}{l}1000-1500 ; \\
1500-2300\end{array}$ \\
\hline Polypodiaceae & Lecanopteris sinuosa (Hook.) Copel. & EN A1a & 00003420 & - & - & - & + & $\mathrm{LM} / \mathrm{UM}$ & $\begin{array}{l}1000-1500 ; \\
1500-2300\end{array}$ \\
\hline Polypodiaceae & Lepisorus platyrhynchos (Kunze) Li Wang & EN A1a & $\begin{array}{l}00011530 \\
00007626\end{array}$ & + & + & - & - & $\mathrm{UM} / \mathrm{MF}$ & $\begin{array}{l}1500-2300 ; \\
2300-2600\end{array}$ \\
\hline Polypodiaceae & Platycerium coronarium (Konig) Desv. & CR B1a & 00011557 & - & - & - & + & LF & $<1000$ \\
\hline Psilotaceae & Psilotum complanatum $\mathrm{Sw}$. & EN A1a & $\begin{array}{l}00011546 \\
00011486 \\
00011560\end{array}$ & - & + & + & + & LF & $<1000$ \\
\hline Psilotaceae & Psilotum nudum (L.) P.Beauv. & VU A1a & $\begin{array}{l}00011526 \\
00011495 \\
00011507\end{array}$ & + & + & - & + & LF & $<1000$ \\
\hline Psilotaceae & $\begin{array}{l}\text { *Tmesipteris zamorarum Gruezo \& } \\
\text { Amoroso }\end{array}$ & EN A1c & $\begin{array}{l}00011535 \\
00006720 \\
00011489\end{array}$ & + & + & + & - & $\mathrm{UM} / \mathrm{MF}$ & $\begin{array}{l}1500-2300 \\
2300-2600\end{array}$ \\
\hline Pteridaceae & Doryopteris kirkii (Hook.) Alston & EN B1a & 00011565 & - & - & - & + & LF & $<1000$ \\
\hline Selaginellaceae & $\begin{array}{l}\text { Selaginella tamariscina (P.Beauv.) } \\
\text { Spring }\end{array}$ & EN B2a & 00011520 & - & - & - & + & LF & $<1000$ \\
\hline Schizaeaceae & Actinostachys inopinata (Selling) C.F.Reed & EN B1a & 00003309 & - & - & - & + & LF/FUS & $<1000$ \\
\hline Schizaeaceae & Schizaea malaccana Baker & EN B2a & 00011487 & - & - & - & + & LF/FUS & $<1000$ \\
\hline \multicolumn{4}{|c|}{ TOTAL } & 29 & 28 & 27 & 19 & & \\
\hline
\end{tabular}

Note: CR - Critically Endangered, EN - Endangered, VU - Vulnerable, OTS - Other Threatened Species; CMUH - Central Mindanao University Herbarium; «+» indicates presence of species, «-» indicates absence of species, asterisk $(*)$ before the scientific name indicates the species endemic to the Philippines; MS - mossy forest, UP - upper montane forest, LM - lower montane forest, LF - lowland forest, FUS - forest over ultramafic soil.

Helminthostachys zeylanica (L.) Hook.

Helminthostachys zeylanica (Ophioglossaceae) is a herbaceous fern usually with a solitary frond and a fertile spike that arises from the base of its frond (Fig. 2C). This species is locally known as «tungkod-langit» and generally found at lower altitudes on wet and muddy places. It was recorded only in Mt. Malindang Range Natural Park for this study.
In some countries like Brunei, it is commonly sold at the market as vegetables and medicine (de Winter $\&$ Amoroso, 2003). However, there are no reports from the Philippines that this species is edible.

Distribution. This species is widely distributed in the Palaeotropics, from Sri Lanka and India (Assam) to New Caledonia and Australia. Philippines: Palawan and Mindanao (Mt. Malindang Range Natural Park). 

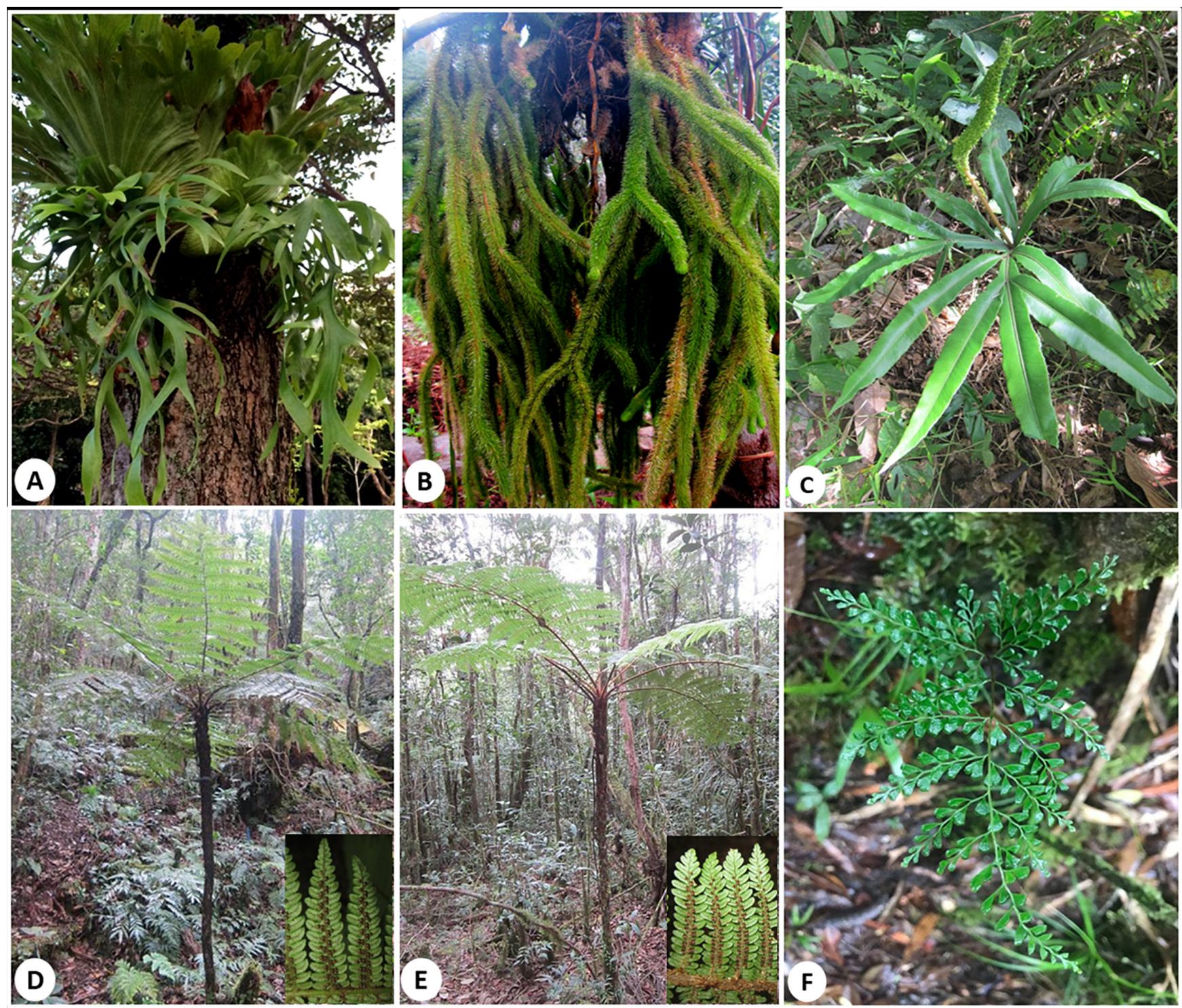

Fig. 2. Critically Endangered and Mindanao endemic lycophytes and ferns. Designations: A: Platycerium coronarium; B: Phlegmariurus magnusianus; C: Helminthostachys zeylanica; D: Alsophila hermannii; E: Alsophila rufopannosa; F: Lindsaea hamiguitanensis.

Threatened and endemic species of Mindanao Alsophila hermannii R.M.Tryon

Alsophila hermannii is a medium-size scaly tree fern of the family Cyatheaceae. Trunks are erect to 4(-6) $\mathrm{m}$ height, to $24-27 \mathrm{~cm}$ diameter with old petiole bases and with marginate light to dark brown scales (Fig. 2D). The species was known only from its type locality on Mt. Apo. However, our study recorded this species in the Mt. Kitanglad Range Natural Park growing in the upper montane to the mossy forests (2000-2300 m a.s.1.).

Distribution. Mindanao: North Cotabato (Mt. Apo Natural Park) and Bukidnon (Mt. Kitanglad Range Natural Park).

\section{Alsophila rufopannosa (Christ) R.M.Tryon}

Alsophila rufopannosa (Cyatheaceae) is a fern endemic to Mindanao Island. It is also a medium size tree fern with trunks erect to $4(-6) \mathrm{m}$ height, and to
$15-18 \mathrm{~cm}$ diameter, without old petiole bases and with numerous marginate reddish brown scales on petioles and rachises (Fig. 2E). It was previously known only from San Ramon, Zamboanga and recently it has been recorded in Mt. Malindang Range Natural Park and Mt. Pantaron Range, Central Mindanao.

Distribution. Mindanao: Zamboanga (San Ramon), Misamis Occidental (Mt. Malindang Range Natural Park), Bukidnon (Mt. Pantaron and Mt. Kiamo).

\section{Lindsaea hamiguitanensis D.N.Karger \& V.B.Amoroso \\ Lindsaea hamiguitanensis is a small herba- ceous fern with triangular, bipinnate to tripinnate- pinnatifid fronds that are light green when dry, with reddish brown and quadrangular rachises (Fig. 2F). This species was discovered in Mt. Hamiguitan Range Wildlife Sanctuary in 2012 and has recently}


been documented in Mt. Tago and Mt. Pantaron Range in Bukidnon, Central Mindanao.

Distribution. Mindanao: Davao Oriental (Mt. Hamiguitan Range Wildlfie Sanctuary) and Bukidnon (Mt. Tago and Mt. Pantaron Range).

In total there are 291 endemic species of ferns and lycophytes in the Philippines (Barcelona, 20112020), with about 94 of them considered also by DAO 2017-11 as threatened. In this study, the threatened endemic species include Phlegmariurus magnusianus, Alsophila apoensis (Copel.) R.M.Tryon, A. atropurpurea (Copel.) C.Chr., A. hermannii, A. fuliginosa Christ, A. heterochlamydea (Copel.) R.M.Tryon, A. negrosiana (Christ) R.M.Tryon, A. rufopannosa, Lindsaea hamiguitanensis, Tmesipteris zamorarum Gruezo \& Amoroso, Aglaomorpha cornucopia (Copel.) M.C.Roos, and A. sagitta (Christ) Hovenkamp \& S. Linds. Among these, Alsophila hermannii, A. rufopannosa, and Lindsaea hamiguitanensis are endemic only to Mindanao. The family Cyatheaceae has the most threatened endemic species, with $70 \%$ of the total number of the scally tree ferns recorded. All species in this tree fern family are listed in the Convention on Interna- tional Trade in Endangered Species of Wild Fauna and Flora (CITES) Appendix II in which the species are not necessarily threatened with extinction, but their trade must be controlled in order to avoid utilisation incompatible with their survival.

Other threatened ferns found on the study sites are species of Psilotaceae, Schizaeaceae, Lecanopteris, Selaginella tamariscina (P.Beauv.) Spring and Ophioderma pendula C.Presl. Members of the family Psilotaceae are unusual looking ferns that are rootless and sometimes leafless as in Psilotum. In the Philippines, all of the Psilotaceae species are considered as threatened, namely Psilotum nudum (L.) P.Beauv. (VU) (Fig. 3A), Psilotum complanatum Sw. (EN) and Tmesipteris zamorarum (EN) (Fig. 3B). Psilotum nudum and $P$. complanatum were observed growing on tree fern trunks of Sphaeropteris polypoda (Baker) R.M.Tryon in Mt. Hamiguitan Range Wildlife Sanctuary. Tmesipteris zamorarum also grows only on tree fern species trunks of Cyatheaceae and Dicksoniaceae. This species was recorded only in high mountain ecosystems above 2000 m a.s.1., such as Mt. Apo Natural Park, Mt. Kitanglad Range Natural Park and Mt. Malindang Range Natural Park.

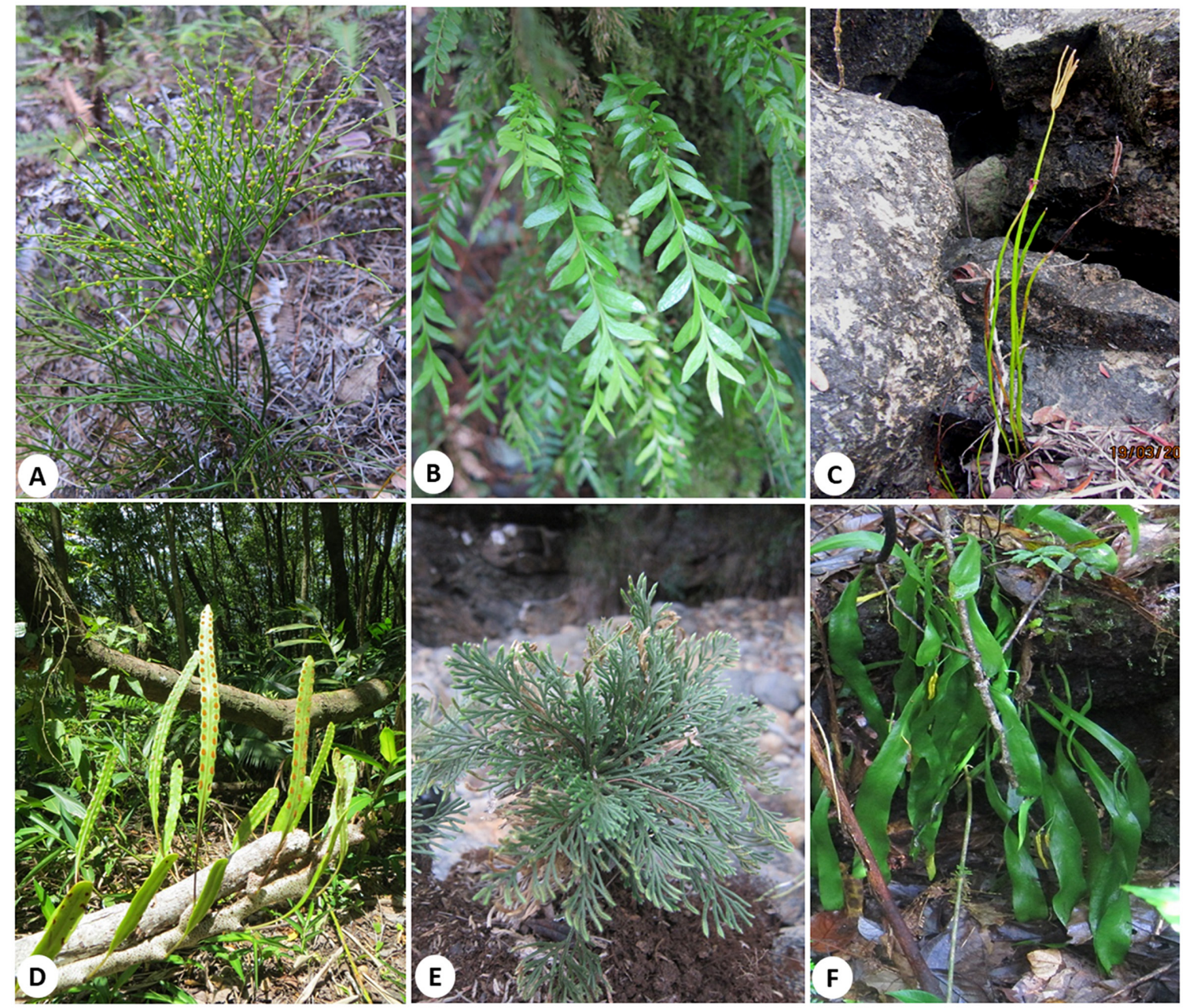

Fig. 3. Some threatened ferns and lycophytes. Designations: A: Psilotum nudum; B: Tmesipteris zamorarum; C: Actinostachys inopinata; D: Lecanopteris sinuosa; E: Selaginella tamariscina; F: Ophioderma pendula. 
There are five Schizaeaceae species reported in the Philippines. All of these are found in Mt. Hamiguitan Range Wildlife Sanctuary (Amoroso et al., 2020). Two species are considered as Endangered, namely Actinostachys inopinata (Selling) C.F.Reed (Fig. 3C) and Schizaea malaccana Baker. These species are found in forests on ultramafic soil in Mt. Hamiguitan Range Wildlife Sanctuary, growing together with Schizaea dichotoma (L.) Sm. Two species of «ant ferns» of the genus Lecanopteris are present, namely $L$. deparioides (Ces.) Baker and L. sinuosa (Hook.) Copel. (Fig. 3D). These species are epiphytes on trees, like Leptospermum polygalifolium Salisb. subsp. polygalifolium, Sphaeropteris spp. Lecanopteris deparioides was recorded in Mt. Hamiguitan Range Wildlife Sacntuary and Mt. Malindang Range Natural Park while L. sinuosa was found only in Mt. Hamiguitan Range Wildlife Sanctuary.

Selaginella tamariscina (Fig. 3E) is the only threatened species in the family Selaginellaceae recorded in the four Protected Areas. It is known for its antibacterial, anticancer, antifungal, and antiviral activities (Gechev et al., 2014). It is widely used by the local people in the Philippines to cure diseases (Setyawan, 2009; Amoroso, 2013). Thus, there is over-exploitation of this species in the wild. This species was recorded only in the eastern side of Mt. Hamiguitan Range Wildlife Sanctuary near the river banks growing on rocks and boulders. Ophioderma pendula or «ribbon» fern (Fig. 3F) was recorded in all four Protected Areas on Mindanao. The species is also commonly harvested by the local people in the Philippines and sold cheaply. Most of the species were included in the threatened list of plants for the Philippines because they are widely collected in the wild for their ornamental and medical uses, thus, depleting the population of the species.

\section{Discussion}

There are many reasons why species become threatened or endangered. Habitat destruction through logging, shifting cultivation, land use/ land cover change, environmental pollution, invasive species, grazing, urbanisation, hydrological disturbance, and over-exploitation of forest resources are considered as the major threats to biodiversity worldwide (Catibog-Sinha \& Heaney, 2006; Amoroso et al., 2011; Monastersky, 2014; Khapugin et al., 2020). Climate change is also one of the primary causes of species endangerment (Ibrahim et al., 2013). Moreover, plants are also becoming extinct because of distinctive sequential patterns, with agriculture, invasions, and urbanisation as significant drivers in hotspots, whereas hydrological disturbance is an important driver in coldspots (Le Roux et al., 2019).

The recent assessment of DENR was primarily based on the IUCN criteria applied to information from scientific literature (e.g. geographic distribution of the species, extent of area of occupancy, actual threats of habitat, and over exploitation of high economic or commercial value species), available herbarium specimens, biodiversity survey data and Filipino botanists' field experience and knowledge of the flora.

Most of the threatened lycophytes and ferns $(71 \%)$ are found in mountain ecosystems in different parts of the country. Mt. Apo Natural Park had the highest number of taxa with 29 species, followed by Mt. Kitanglad Range Natural Park (28 species), Mt. Malindang Range Natural Park (27 species), and Mt. Hamiguitan Range Wildlife Sanctuary (19 species). The high number of threatened species in Mt. Apo and Mt. Kitanglad is caused by the diversity of vegetation types in the area like the upper and lower montane forests (Amoroso et al., 2011, 2016b). Most of the threatened tree ferns and lycopods are found in this vegetation type.

Most of the threatened lycophytes and ferns (53\%) inhabited the lower and upper montane forests with an altitude range of 1000-1500 $\mathrm{m}$ a.s.l. and 1500-2300 $\mathrm{m}$ a.s.l., respectively, followed by the lowland forests $(<1000 \mathrm{~m}$ a.s.1.), and the mossy forests (above $2300 \mathrm{~m}$ a.s.1.) (Table, Fig. 4). Species richness of ferns and lycophytes increased with altitude (Acebey et al., 2017). The highest species richness of ferns in the montane forests supports the findings of Bhattarai et al. (2004), Kluge et al. (2006), Kessler et al. (2011), Salazar et al. (2015) that fern richness was the highest in mid-altitudes, usually in montane forests. This has often been linked to an optimal combination of high humidity, rainfall, and moderate temperatures at mid-altitudes (Lauer et al., 1996).

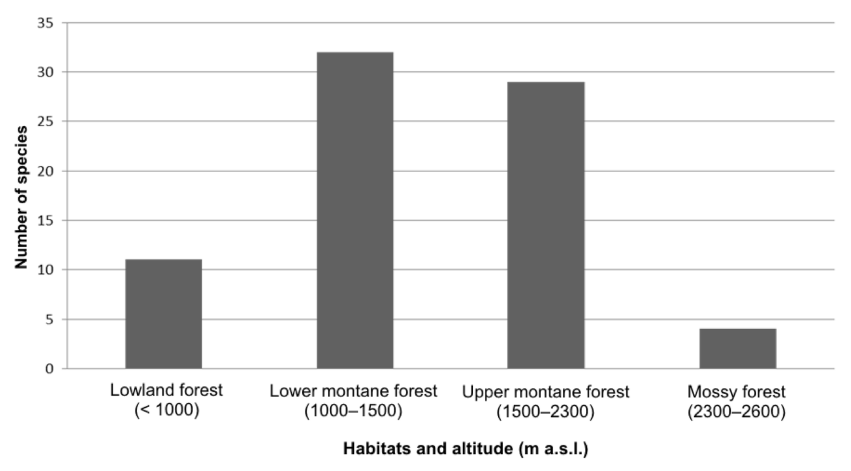

Fig. 4. Species distribution in relation to altitude and habitats in the four Protected Areas of the Mindanao. 
Of all the species recorded, Sphaeropteris glauca (Blume) R.M.Tryon has the widest altitude range of distribution, from the lowland forests up to the upper montane forests. It is also common on all sites where it can grow in full exposure to the sun and very abundant in clearings and open places in the forest. Lepisorus platyrhynchos (Kunze) Li Wang and Tmesipteris zamorarum are restricted to the upper montane and mossy forests. They are epiphytes on tree ferns and trees in association with mosses and liverworts. Moreover, the two Schizaeaceae species are restricted to the forests on ultramafic soil below $1000 \mathrm{~m}$ a.s.1. in Mt. Hamiguitan Range Wildlife Sanctuary.

Some of the threatened endemic species were also recorded in other Protected Areas in the Philippines, like Angiopteris evecta (G.Forst.) Hoffm., Oceaniopteris egregia (Copel.) Gasper \& Salino, Platycerium coronarium and Psilotum nudum in Adams, Northern Luzon (Magtoto \& Austria, 2017), A. evecta in Mt Makiling, Laguna (Alcala et al., 2019), Aglaomorpha splendens (J.Sm.) Copel., Alsophila negrosiana, Dicksonia mollis Holttum, Botrychium daucifolium Wall. ex Hook. \& Grev., Lecanopteris deparioides, Ophioderma pendula, Oceaniopteris egregia, Plenasium banksiifolium (C.Presl) C.Presl, Psilotum nudum and Sphaeropteris glauca in Balinsasayao Twin Lakes Natural Park, Negros Oriental (Amoroso et al., 2016a), Aglaomorpha heraclea (Kunze) Copel., Aglaomorpha speciosa (Blume) M.C.Roos, Asplenium vittaeforme Cav., Davallia solida (G.Forst.) Sw., Lecanopteris sinuosa, Psilotum nudum, Sphaeropteris glauca, and Actinostachys inopinata in Rajah Sikatuna Protected Landscape, Bohol Island (Barcelona et al., 2006), Aglaomorpha splendens, Platycerium coronarium, Phlegmariurus squarrosus (G.Forst.) Á.Löve \& D.Löve, Sphaeropteris glauca in Mindoro Island (Villanueva \& Buot, 2015).

\section{Conclusions}

The presence of threatened lycophytes and ferns on the study sites should be given high priority for conservation and action by the government to prevent their extinction. Communication, education and public awareness about fern diversity and its importance should be done to enhance the awareness of the local communities and of the public in general. Propagation protocols should also be developed to mass propagate these threatened and endemic species of lycophytes and ferns. A complete database about the distribution of threatened lycophytes and ferns in the Philippines should be prepared for easy monitoring of the species. Finally, effective forest management and strict implementation of the ordinances are necessary for the long term conservation and protection not only to lycophytes and ferns but the whole flora and fauna within these Protected Areas.

\section{Acknowledgements}

Financial support for this research from the Department of Science and Technology - Grants-In-Aid (DOST-GIA) is gratefully acknowledged. We also thank the officials of the Department of Environment and Natural Resources, Region X and XII for the gratuitous permit; Barangay officials and our local researchers in Mt. Apo, Mt. Kitanglad, Mt. Malindang and Mt. Hamiguitan for the assistance during fieldwork; and Central Mindanao University headed by Dr. Jesus Antonio G. Derije for logistical support. We acknowledge our company with the National Science Foundation (NSF) researchers headed by Dr. Peter W. Fritsch during the botanical exploration.

\section{References}

Acebey A., Krömer T., Kessler M. 2017. Species richness and vertical distribution of ferns and lycophytes along an elevational gradient in Los Tuxtlas, Veracruz, Mexico. Flora 235: 83-91. DOI: 10.1016/j.flora.2017.08.003

Alcala A.A., de los Angeles M.D., Buot Jr.I.E. 2019. Fern species diversity across various land use types of Mt. Makiling, Luzon Island, Philippines. Biodiversitas 20(9): 2437-2445. DOI: 10.13057/biodiv/d200902

Amoroso V.B. 2013. Medicinal Ferns and Lycopods. Bukidnon, Philippines: Central Mindanao University. 109 p.

Amoroso V., Arances J., Gorne N., Rufila L., Ruba R., Opiso G., Demetillo M., Noval K., Den Ber A., Stortelde A., Kessler P., Gruezo W., Lagunzad D., Tan B., Co L., Aranico E., Roscom B., Alava C. 2006. Plant diversity and status in Northern landscape of Mt. Malindang range and environs, Misamis Occidental, Philippines. BRP Monograph Series No. 8. Laguna: SEAMEO SEARCA. 116 p.

Amoroso V., Obsioma L., Arlalejo J., Aspiras R., Capili D., Polizon J., Sumile E. 2009. Inventory and Conservation of Endangered, Endemic and Economically Important Flora of Hamiguitan Range, Southern Philippines. Blumea 54(1-3): 71-76. DOI: 10.3767/000651909X474113

Amoroso V., Laraga S., Calzada B. 2011. Diversity and assessment of plants in Mt. Kitanglad Range Natural Park, Bukidnon, Southern Philippines. Gardens' Bulletin Singapore 63(1-2): 219-236.

Amoroso V.B., Acma F.P., Dela Cruz R.Y., Coritico F.P., Nietes A.D., Hamo G.B., Lumista H.P. 2015. Diversity of Herbaceous Pteridophytes in Four Mindanao Long Term Ecological Research (LTER) Sites, Philippines. Asia Life Sciences 24(1): 69-85.

Amoroso V.B., Chen C.W., Coritico F.P., Lu P.F., Alcala E.L., Chiou W.L. 2016a. Guide to Lycophytes and Ferns of Balinsasayao, Negros, the Philippines. Pintung, Taiwan: KBCC Press. 150 p. 
Amoroso V.B., Coritico F.P., Fritsch P.W. 2016b. Species Richness and Conservation Status of Ferns and Lycophytes in Mt. Hamiguitan Range Wildlife Santuary, Davao Oriental, Philippines. Philippine Journal of Science 145(2): 17-23.

Amoroso V.B., Mohagan A.B., Coritico F.P., Lagunday N.E., Yorong A.P., Colong R.D., Ponce R.G. 2018. Avifaunal assemblage in the expansion sites of the Mt. Hamiguitan Range Wildlife Sanctuary, Mindanao, Philippines. Nature Conservation Research 3(Suppl.2): 103-109. DOI: $10.24189 /$ ncr.2018.069

Amoroso V.B., Coritico F.P., Fritsch P.W. 2020. Actinostachys minuta, a new species of grass fern from Mindanao, Philippines. Phytokeys 151(3): 59-66. DOI: 10.3897/phytokeys. 151.53100

Aribal L.G., Buot Jr.I.E. 2009. The threatened plants species in various regions in Mindanao Island, Philippines. Journal of Nature Studies 8(2): 23-33.

Barcelona J., Dolotina N., Madroñero G., Granert W., Sopot D. 2006. The ferns and fern allies of the karst forests of Bohol Island, Philippines. American Fern Journal 96(1): 1-20. DOI: 10.1640/0002-8444(2006)96[1:TF AFAO]2.0.CO;2

Barcelona J. 2011-2020. Pteridophytes (Lycophytes and Monilophytes). In: P.B. Pelser, J.F. Barcelona, D.L. Nickrent (Eds.): Co's Digital Flora of the Philippines. Available from https://www.philippineplants.org/

Bhattarai K.R., Vetaas O.R., Grytnes J.A. 2004. Fern species richness along a central Himalayan elevational gradient, Nepal. Global Ecology and Biogeography 31(3): 389-400. DOI: 10.1046/j.0305$-0270.2003 .01013 . x$

Catibog-Sinha C., Heaney L. 2006. Philippine Biodiversity: Principles and Practice. Quezon City: Haribon Foundation for the Conservation of Natural Resources Inc. $495 \mathrm{p}$.

Copeland E. 1958. Fern flora of the Philippines. Vol. 1-3. Manila: Manila Bureau of Printing. 555 p.

de Winter W.P., Amoroso V.B. 2003. Cryptogams: ferns and fern allies. Leiden: Backhuys Publishers. $271 \mathrm{p}$.

DENR-DAO. 2017. Updated National List of Threatened Philippine Plants and their Categories. Philippines: Business Mirror. $30 \mathrm{p}$.

Ebihara A., Fraser-Jenkins C.R., Parris B.S., Zhang X.C., Hong Y.Y., Chiou W.L., Chang H.M., Lindsay S., Middleton D., Kato M., Praptosuwiryo T.N., Amoroso V.B., Barcelona J.F., Rajapaksha R.H.G., Park C.H., Murakami N., Hoya A. 2012. Rare and Threatened Pteridophytes of Asia 1. An Enumeration of Narrowly Distributed Taxa. Bulletin of the National Museum of Nature and Science, Series B 38(3): 93-119.

Fernando E., Co L., Lagunzad D., Gruezo W., Barcelona J., Madulid D., Lapis A., Texon G., Manila A., Zamora P. 2008. Threatened Plants of the Philippines: A Preliminary Assessment. Asia Life Sciences Suppl.3: 1-52.

Gechev T.S., Hille J., Woerdenbag H.J., Benina M., Mehterov N., Toneva V., Fernie A.R., Mueller-Roeber B. 2014. Natural products from resurrection plants: Potential for medical applications. Biotechnology Advances 32(6): 1091-1101. DOI: 10.1016/j.biotechadv.2014.03.005
Hodge W. 1947. The use of alcohol in plant collecting. Rhodora 49: 207-210.

Ibrahim M.A., Na M., Oh J., Schinazi R.F., McBrayer T.R., Whitaker T., Doerksen R.J., Newman D.J., Zachos L.G., Hamann M.T. 2013. Significance of endangered and threatened plant natural products in the control of human disease. Proceedings of the National Academy of Sciences of the United States of America 110(42): 16832-16837. DOI: 10.1073/ pnas. 1311528110

Kessler M., Kluge J., Hemp A., Ohlemüller R. 2011. A global comparative analysis of elevational species richness patterns of ferns. Global Ecology and Biogeography 20(6): 868-880. DOI: 10.1111/j.1466-8238.2011.00653.x

Khapugin A.A., Kuzmin I.V., Silaeva T.B. 2020. Anthropogenic drivers leading to regional extinction of threatened plants: insights from regional Red Data Books of Russia. Biodiversity and Conservation 29(8): 2765 2777. DOI: 10.1007/s10531-020-02000-X

Kim E.S., Trisurat Y., Muraoka H., Shibata H., Amoroso V.B., Boldgiv B., Hoshizaki K., Kassim A.R., Kim Y.S., Nguyen H.Q., Ohte N., Ong P.S., Wang C.P. 2017. The International Long-Term Ecological Research - East Asia - Pacific Regional Network (ILTER-EAP): history, development, and perspectives. Ecological Research 33(1): 19-34. DOI: 10.1007/s11284-017-1523-7

Kluge J., Kessler M., Dunn R. 2006. What drives elevational patterns of diversity? A test of geometric constraints, climate and species pool effects for pteridophytes on an elevational gradient in Costa Rica. Global Ecology and Biogeography 15(4): 358-371. DOI: 10.1111/j.1466-822X.2006.00223.X

Lauer W., Rafiqpoor M., Frankenberg P. 1996. Die Klimate der Erde: Eine Klassifikation auf ökophysiologischer Grundlage der realen Vegetation. Erdkunde 50(4): 275-300.

Le Roux J.J., Hui C., Castillo M.L., Iriondo J.M., Keet J.H., Khapugin A.A., Médail F., Rejmánek M., Theron G., Yannelli F.A., Hirsch H. 2019. Recent anthropogenic plant extinctions differ in biodiversity hotspots and coldspots. Current Biology 29(17): 2912-2918. DOI: 10.1016/j.cub.2019.07.063

Lindsay S., Middleton D.J. 2012-2020. Ferns of Thailand, Laos and Cambodia. Available from http://rbg-web2. rbge.org.uk/thaiferns/

Lumista H.P., Dela Cruz R.Y., Acma F.M., Amoroso V.B. 2016. Occurrence of Threatened, Endemic, and Economic Seed Plants in Selected Mountains in Mindanao, Philippines. CMU Journal of Science 20(1): 2-13.

Magtoto L.M., Austria C.M. 2017. The Pteridophytes of Adams, Northern Luzon, Philippines and their Ecosystem Services. Philippine Journal of Systematic Biology 11(2): 43-51.

Mohagan A.B., Nuñeza O.M., Escarlos J.A.Jr., Gracia Jr.A.G., Selpa E.C.T., Baguhin L.J.B., Coritico F.P., Amoroso V.B. 2015. Diversity and endemism of terrestrial mammals in four long term ecological research sites in Mindanao, Philippines. Asia Life Sciences 24(1): 219-233. 
Mohagan A.B., Nuñeza O.M., Diesmos A.C., Escarlos Jr.J.A., Gracia Jr.A.G., Selpa E.C.T., Baguhin L.J.B., Coritico F.P., Amoroso V.B. 2018. Anuran Species Richness and Endemism in Four Long-Term Ecological Research Sites in Mindanao, Philippines. Asian Journal of Conservation Biology 7(2): 83-91.

Monastersky R. 2014. Biodiversity: life - a status report. $\mathrm{Na}$ ture 516: 158-161. DOI: 10.1038/516158a

Moran R.C. 2008. Diversity, biogeography, and floristics. In: T.A. Ranker, C.H. Haufler (Eds.): Biology and Evolution of Ferns and Lycophytes. New York: Cambridge University Press. P. 367-394.

PPG I. 2016. A community-derived classification for extant lycophytes and ferns. Journal of Systematics and Evolution 54(6): 563-603. DOI: 10.1111/jse.12229
Salazar L., Homeier J., Kessler M., Abrahamczyk S., Lehnert M., Krömer T., Kluge J. 2015. Diversity patterns of ferns along elevational gradients in Andean tropical forests. Plant Ecology and Diversity 8(1): 13-24. DOI: 10.1080/17550874.2013.843036

Setyawan A.D. 2009. Traditionally utilization of Selaginella; field research and literature review. Nusantara Bioscience 1(3): 146-154.

Smith A., Pryer K., Schuettpelz E., Korall P., Schneider H., Wolf P. 2006. A classification for extant ferns. Taxon 55(3): 705-731. DOI: 10.2307/25065646

Villanueva E.L.C., Buot Jr.I.E. 2015. Threatened Plant Species of Mindoro, Philippines. IAMURE International Journal of Ecology and Conservation 14(1): 168-190.

\title{
ПЛАУНОВЫЕ И ПАПОРОТНИКОВЫЕ РАСТЕНИЯ, НАХОДЯЩИЕСЯ ПОД УГРОЗОЙ ИСЧЕЗНОВЕНИЯ, НА ЧЕТЫРЕХ ОСОБО ОХРАНЯЕМЫХ ПРИРОДНЫХ ТЕРРИТОРИЯХ В МИНДАНАО (ФИЛИППИНЫ)
}

\author{
Ф. П. Коритико*, В. Б. Аморосо \\ Центральный университет Минданао, Филиппины \\ *e-mail: cfulgent@gmail.com
}

На Филиппинах известно около 1000 видов сосудистых растений, находящихся под угрозой исчезновения, из которых около $12 \%$ составляют плауновые и папоротниковые. Однако данных о распространении этих видов недостаточно. В связи с этим целью настоящего исследования стало изучение находящихся под угрозой исчезновения плауновых и папоротниковых растений на основании полевых исследований на четырех особо охраняемых природных территорий Минданао: Природный парк горы Апо, Природный парк горного хребта Китанглад, Природный парк горного хребта Малинданг и Заказник дикой природы горного хребта Хамигутан. Оценка природоохранного статуса видов была основана на списке находящихся под угрозой исчезновения растений Филиппин, обновленном Департаментом окружающей среды и природных ресурсов DAO 2017-11. Было зарегистрировано 45 видов плауновых и папоротниковых растений, находящихся под угрозой исчезновения, принадлежащих к 16 семействам и 25 родам, в том числе три вида, находящихся под угрозой исчезновения (CR), 23 исчезающих (EN) вида, 15 уязвимых (VU) вида, а также три других угрожаемых (предположительно, NT) вида. Следующие семейства включают наибольшее число видов, находящихся под угрозой исчезновения: Cyatheaceae, Polypodiaceae, Lycopodiaceae, Ophioglossaceae, Psilotaceae. К видам, находящимся под угрозой исчезновения (CR) относятся Platycerium coronarium, Phlegmariurus magnusianus, Helminthostachys zeylanica. Следующие находящиеся под угрозой исчезновения виды являются эндемичными для Филиппин: Phlegmariurus magnusianus, Alsophila apoensis, A. atropurpurea, A. hermannii, A. fuliginosa, A. heterochlamydea, A. negrosiana, A. rufopannosa, Lindsaea hamiguitanensis, Tmesipteris zamorarum, Aglaomorpha cornucopia, A. sagitta. Наибольшее число находящихся под угрозой исчезновения таксонов было отмечено в Природном парке горы Апо (29 видов), меньшее число - в Природном парке горного хребта Китанглад (28 видов), Природном парке горного хребта Малинданг (27 видов) и Заказнике дикой природы горного хребта Хамигутан (19 видов). Наибольшее число видов плауновых и папоротниковых было отмечено в нижних и верхних поясах горных лесов. Произрастание находящихся под угрозой исчезновения и эндемичных видов плауновых и папоротниковых растений на четырех особо охраняемых природных территориях требует строгого выполнения постановлений, необходимых для долгосрочного сохранения и защиты этих видов.

Ключевые слова: горные экосистемы, исчезающий вид, папоротникообразные, сохранение, эндемизм 